I nhi bi tory effects of adhesi on ol i gopept i des on the i nvasi on of squanous car ci noma cel I s wi th speci al reference to i mpl ication of $a v$ i nt egrins

\begin{tabular}{|l|l|}
\hline 著者 & $\begin{array}{l}\text { Kawahar a Ei, I mai Kazushi, Kumagai Shi gehi ro, } \\
\text { Yamanto o Et suhi de, Nakani shi I sao }\end{array}$ \\
\hline $\begin{array}{l}\text { j our nal or } \\
\text { publ i cat i on t i t l e }\end{array}$ & $\begin{array}{l}\text { Journal of Cancer Research and Cl i ni cal } \\
\text { Oncol ogy }\end{array}$ \\
\hline vol ume & 121 \\
\hline number & 3 \\
\hline page r ange & 133 140 \\
\hline year & $1995-01-01$ \\
\hline URL & ht t p: //hdl . handl e. net /2297/1661 \\
\hline
\end{tabular}




\section{Inhibitory Effects of Adhesion Oligopeptides on the Invasion of Squamous Carcinoma Cells with Special Reference to Implication of $\alpha v$ Integrins}

Ei Kawahara1, Kazushi Imai ${ }^{2}$, Shigehiro Kumagai ${ }^{2}$, Etsuhide Yamamoto $^{2}$ and Isao Nakanishi ${ }^{1}$

1Department of Pathology, School of Medicine, Kanazawa University, 13-1

Takara-machi, Kanazawa, Ishikawa 920, Japan

2Department of Oral and Maxillo-facial Surgery, School of Medicine, Kanazawa University, 13-1 Takara-machi, Kanazawa, Ishikawa 920, Japan

FAX number (Ei Kawahara) 0762-34-4228

This work was supported in part by a grant from the Osaka Cancer Research Foundation.

Abbreviations: ECM, extracellular matrix; BSA, bovine serum alubumin; MEM, Eagle's minimum essential medium; MTT, 3-(4, 5-dimethylthiazol-2-yl)-2, 5-diphenyltetrazolium bromide; PBS, phosphate buffered saline; SDS-PAGE, sodium dodecyl sulfate-polyacrylamide gel electrophoresis; FITC, fluorescein isothiocyanate

Correspondence to: E. Kawahara 


\begin{abstract}
We studied invasion-related adhesion events in vitro using three squamous carcinoma cell lines (HSC-3, poorly differentiated type; OSC-19, welldifferentiated type; and KB cells, undifferentiated type). In vitro invasion assay through matrigel in the transwell chamber revealed that HSC-3 cells were most invasive, OSC-19 cells moderately invasive and KB cells least invasive. By inhibition assay of invasion using synthetic peptides RGD, RGDV, RGDS, RGDT, IKVAV and YIGSR, invasion of three cell lines was significantly inhibited by RGDV. There were another peptides which inhibited invasion significantly including IKVAV for HSC-3, RGDS and YIGSR for OSC-19. HSC-3 cells and OSC-19 cells adhered to fibronectin, laminin, vitronectin, and type IV collagen, and KB cells did not adhere to laminin but did to fibronectin, vitronectin and collagen type IV. Pretreatment of cells with RGDV peptide in the attachment assay reduced binding ability of these cells to vitronectin and fibronectin more efficiently than pretreatment with RGDS. Anti- $\alpha$ v antibodies inhibited adhesion of HSC-3, OSC-19 and KB cells to vitronectin, but anti- $\beta 1$ antibodies did not inhibit adhesion. Immunofluorescent microscopic examinations showed that all cell lines were positive for anti- $\beta 5$ and anti- $\alpha \mathrm{V}$ antibodies, and only HSC-3 cells were positive for anti- $\beta 3$ antibody. $\alpha 5 \beta 1$ was not clearly demonstrated in all cell lines. RGDV was most effective inhibitor of squamous cell carcinoma invasion among synthetic oligopeptides used in this experiment, and it was suggested that it affected $\alpha v \beta 3$ and/or $\alpha v \beta 5$-mediated carcinoma cell invasion.
\end{abstract}

Key Words: Integrin - Squamous cell carcinoma - Invasion assay - RGDV 


\section{INTRODUCTION}

Attachment of carcinoma cells to the extracellular matrix (ECM) and the subsequent cellular movement are important steps for the cell invasion. Integrins which form a superfamily in compliance with a combination of subunits are cell surface receptor for ECM, and integrin expression is believed to affects adhesiveness of cells to ECM proteins and following migration (Ruoslahti and Giancotti 1989; Albelda 1993; Evans 1992). Although a good correlation between integrin expression and tumor progression has been noted in melanoma cells and glial tumor cells (Cheresh 1991; Gladson and Cheresh 1991), the pattern of integrin expression on the other types of malignant tumors appears to be complicated (Korhonen et al. 1992, Miettinen et al. 1993), and there is no distinct aggreement to address which integrins are responsible for invasion and metastasis of tumor cells.

Synthetic peptide analogs of adhesive proteins have been used as potential blockers of distinct integrins in vitro and in vivo (Hirano et al. 1991; Kramer et al. 1986; Steiner et al. 1989; Chen et al. 1991). Since the first demonstration by Pierschbacher and Ruoslahti (1984) of a recognition determinant on fibronectin for $\alpha 5 \beta 1$ consisting of the Arg-Gly-Asp (RGD) amino acid sequence, many studies have convinced that this sequence has been a minimal determinant of integrin recognition on many adhesive proteins, including fibronectin, vitronectin, collagen and laminin that bind to the $\beta 1, \beta 3, \beta 5$ and $\beta 6$ family of integrins. Although this observation was of fundamental importance, the RGD sequence alone cannot account for the specificity of integrins for adhesive proteins (Yamada 1991). It has been reported that the activity of oligopeptides depends on X of RGDX sequence (Hirano et al. 1991; Pierschbacher and Ruoslahti 1984). The determinants of adhesion proteins 
responsible for integrin selectivity have been the subject of active investigation to address whether they are selective toward carcinoma cell integrins to inhibit invasion.

In the present study, we have examined inhibitory activity, specificity and selectivity of RGD(X) peptides encompassing the cell binding domains of fibronectin, vitronectin, collagen and laminin on squamous cell carcinoma invasion as well as synthetic peptides of non-integrin laminin receptors. The expression of integrins and their involvement in the invasion was also examined and it has been suggested that $\alpha v$ integrins have been involved in invasion of squamous cell carcinomas. 


\section{MATERIALS AND METHODS}

\section{Cell culture}

Established cell lines originating from human squamous cell carcinomas (OSC-19, HSC-3 and KB) were used. OSC-19 cells are of well-differentiation (Yokoi et al. 1988) and provided by Dr. Kohama (Department of Maxillo-facial Surgery, Sapporo Medical College, Sapporo, Japan). HSC-3 cells of poorlydifferentiated type (Momose et al. 1989) and KB cells of undifferentiated type (Eagle 1955) were provided by Japanese Cancer Research Resource Bank. KB cells have been reported to express HeLa cell marker (Nelson-Pees et al. 1974).

\section{Synthetic peptides}

Oligopeptides of Arg-Gly-Asp (RGD), Arg-Gly-Asp-Ser (RGDS) and ArgGly-Glu-Ser (RGES) were purchased from Bachem Inc. (Torrance, CA, USA), and Arg-Gly-Asp-Val (RGDV), Thr-Ile-Gly-Ser-Arg (YIGSR) and Arg-GlyAsp-Thr (RGDT) were from Peninsula Laboratories Inc. (Belmont, CA, USA). Ile-Lys-Val-Ala-Val (IKVAV) was synthesized by using an automated model 431A synthesizer (Applied Biosystems, Foster city, CA, USA) followed by high performance liquid chromatography.

RGDS is a cell-binding site of fibronectin (Pierschbacher and Ruoslahti 1984), YIGSR of laminin B1 chain (Graf et al. 1987), IKVAV of laminin A chain (Tashiro et al. 1989), RGDV of vitronectin (Suzuki et al. 1985), and RGDT of collagen (Pierschbacher and Ruoslahti 1984). RGD is a minimum adhesion peptide sequence existed in many adhesive ligands for integrins, and RGES is used as a control oligopeptide with no binding activity.

\section{Invasion assay}

The invasiveness of cell lines was measured by using transwell chamber of $12 \mu \mathrm{m}$ pores (Coaster, Cambridge, MA, USA) coated with reconstituted basement 
membrane matrigel which contained laminin, collagen type IV, vitronectin, heparan sulfate proteoglycan and entactin as previously described (Kramer et al. 1986; Seftor et al. 1992) with some modification. Reconstituted basement membrane was prepared with $500 \mathrm{mg} / \mathrm{ml}$ of matrigel diluted in Eagle's minimum essential medium (MEM, Flow Laboratories, Irvine, Scottland) containing 10\% fetal bovine serum. Matrigel (150 mg) was solidated by air-dry in room temperature under sterile condition and subsequently $400 \mathrm{ml}$ of the medium was added on the upper chamber. Carcinoma cells at a concentration of $2 \times 10^{5}$ cells/ chamber were overlaid on matrigel, and $0.6 \mu \mathrm{mol}$ of oligopeptides was added in the upper chamber. The lower chamber was filled with $1.5 \mathrm{ml}$ of the medium. After incubation for $17 \mathrm{hr}$ at $37 \mathrm{C}$ in a $\mathrm{CO} 2$ incubator, invading cells through matrigel into the lower chamber were collected and centrifuged at 5,000 rpm for 4 min using a microtest tube. Cells attached on the wall and roof of the lower chamber were also collected by trypsinization. The numbers of invaded cells were counted by fluorometric assay (Huschtscha et al. 1989). The significance of difference of inhibition was determined by one way analysis of variance and followed by contrast statements using Statistical Analysis System.

\section{Fluorometric assay}

Each cell sample was washed twice with PBS, pH 7.4, suspended in freshly prepared $2 \mathrm{ml}$ of fluorometric assay solution containing $1.2 \mathrm{mM} 4-$ methylumbelliferyl phosphate (Sigma, St. Louis, MO, USA), $1 \mathrm{mM} \mathrm{MgCl}$, and $0.2 \mathrm{mM}$ boric acid, and incubated for $3 \mathrm{hr}$ at 37ロ C. The relative fluorescence of 4-methylumbelliferone was measured using a Fluorescence Electrophotometer 850 (Hitachi, Tokyo, Japan). The wavelength of the excitation and the emission were 345 and $447 \mathrm{~nm}$, respectively. The numbers of cells in the lower chamber without supplement of synthetic peptides in this invasion assay were regarded as 
$100 \%$ of invasion and the proportions of invaders treated with the peptides were determined.

\section{Cell attachment assay}

The attachment assay was performed as previously described elsewhere (Leaversley et al. 1992). Briefly, flat-bottomed plates (3042 Micro Test I, Falcon Products, Oxnard, CA, USA) were coated with $10 \mathrm{mg} / \mathrm{ml}$ of laminin, vitronectin, fibronectin, collagen type I and IV, and BSA overnight at $4 \square \mathrm{C}$. Each substrate was purified as previously described; that is, vitronectin and fibronectin were from human plasma (Yatohgo et al. 1988; Kawahara et al. 1989) collagen type I and IV from human placenta (Ueda et al. 1989; Minamoto et al. 1988) and mouse laminin were isolated from Engelbreth-Holm-Swarm tumor (Kleinman et al. 1982) $1 \times 10^{5}$ cells with triplicates were added in 5\% BSA in serum-free medium (MEM) and incubated until $4 \mathrm{hr}$ at 370 $\mathrm{C}$ to allow the cells to attach on the substrate. To count the number of attached cells, the MTT assay (Mosmann 1983) performed. After removing non-attached cells by washing, the plates were filled with $100 \mathrm{ml}$ the medium and $10 \mathrm{ml} \mathrm{3-(4,5-dimethylthiazol-2-}$ yl)-2, 5-diphenyltetrazolium bromide (MTT, Sigma, St. Louis, MO, USA) solution (5 mg/ml in PBS), then incubated for $4 \mathrm{hr}$ at $370 \mathrm{C}$. At the end of the enzymatic reaction the insoluble dye product was solubilized with of dimethylsulphoxide with mixing thoroughly. Subsequently, the absorbance at 492 nm was read with EIA Reader 2550 (Bio-Rad Lab., Richmond, CA, USA).

\section{Antibodies}

Anti- $\alpha 2 \beta 1, \alpha 3 \beta 1$ and $\alpha 5 \beta 1$ monoclonal antibodies were purchased from DAKO corporation (USA), and anti-vitronectin receptor $(\alpha v)$ polyclonal antibodies were purchased from Telios Pharmaceuticals (LaJolla, CA, USA). Anti- $\alpha v \beta 3$ polyclonal antibodies were kindly provided by Dr. B. Vogel, anti- $\beta 3$ 
antibody (AP3) by Dr. P. Newmann, and anti- $\beta 5$ antibody (IVF2) by Dr. M. Hemler (Pasqualini et al. 1993). 


\section{Immunoprecipitation of integrins}

Cell surface proteins were iodinized with ${ }^{125}$ I using lactoperoxidase (Sonnenberg et al. 1987). 125I-labeled cells were homogenized in $25 \mathrm{mM}$ Tris$\mathrm{HCl}$ buffer, 2\% NP-40, 100mM NaCl, CaCl2, pH 7.6, containing $1 \mathrm{mM}$ diisopropylfluorophosphate, $2 \mathrm{mM}$ phenylmethyl-sulphonyl fluoride, $10 \mathrm{mM}$ 6amino-n-caproic acid, $1 \mu \mathrm{g} / \mathrm{ml}$ leupeptin, $1 \mathrm{mM}$ n-ethyl-maleimide, and $10 \mu \mathrm{g} / \mathrm{ml}$ aprotinin at room temperature, and the supernatant was incubated with polyclonal anti- $\alpha v \beta 3$ antibodies for $1 \mathrm{hr}$ at $4^{\circ} \mathrm{C}$. The solution was applied to protein GSepharose (Pharmacia-LKB, Uppsala, Sweden). The immunocomplexes bound with protein $\mathrm{G}$ were eluted by $0.1 \mathrm{M}$ glycine- $\mathrm{HCl}$, and run in SDS-PAGE (7.5\%) under non-reducing condition. The electrophoresed 125 I-labeled proteins were visualized by autoradiography with preflashed X-Omat AR films (Eastman Kodak Co. Rochester, NY).

\section{Immunofluorescent microscopy}

Cells $\left(0.6 \times 10^{4}\right.$ cells/ $\left.\mathrm{ml}\right)$ in serum-free medium were plated on slide glasses coated with purified human fibronectin and vitronectin, collagen and laminin (10 $\mathrm{mg} / \mathrm{ml}$ ), and incubated for $2 \mathrm{hr}$ and $17 \mathrm{hr}$. Attached cells were fixed with $1 \%$ paraformaldehyde for $3 \mathrm{~min}$ at room temperature. The cells were reacted with primary antibodies to integrins for $60 \mathrm{~min}$ at room temperature. FITCconjugated secondary antibodies were added and incubated for $60 \mathrm{~min}$ at room temperature. As a negative control mouse Ig $\mathrm{G}$ was substituted for a primary antibody. The dilutions of monoclonal anti- $\alpha 2 \beta 1,-\alpha 3 \beta 1,-\alpha 5 \beta 1,-\beta 3$ and $-\beta 5$ antibodies and polyclonal anti- $\alpha v$ antibodies were 500, 500, 500, 1,000 and 1,000, respectively. The dilutions of FITC-conjugated anti-mouse Ig G antibodies and anti-rabbit Ig G antibodies (Cappel, West Chester, PA, USA) were 20. 


\section{RESULTS}

\section{Content of vitronectin and fibronectin in the present invasion assay}

Seftor et al. (1992) first reported the presence of vitronectin in matrigel (25 $\mathrm{mg} / \mathrm{ml}$ ) using immunoblotting examination. We also confirmed the presence of vitronectin in matrigel (18 mg/ml) by immunoblotting and sandwich ELISA method. Fibronectin was not detected in matrigel. But, fibronectin derived from FBS added in the matrigel dilution should be contained in reconstituted basement membrane. Production of fibronectin from OSC-19 cells in plastic dishes, but not from HSC-3 cells, was apparently observed by immunoblotting. Vitronectin derived from those cells were not detected (data not shown).

\section{Invasiveness of cells through reconstituted basement membrane}

Our preliminary invasion assay on time course (4, 8, 16 and $24 \mathrm{hr}$ ) showed that the number of invaded OSC-19 cells traversing through the entire thickness of matrigel increased rapidly within $16 \mathrm{hr}$ followed by gradual increase until 24hr, and then we chose the $17 \mathrm{hr}$ assay. Since the present invasion assay system could be influenced by cell densities on culture dishes, probably resulting from alteration of integrin expression (Larjava 1990), we checked the density of OSC19 cells on plastic culture dishes adequate for the invasion assay. Cells cultured in a sparse density $(6,000 \pm 3,000$ cells/cm²) invaded most actively $(11,000 \pm$ 2,100 cells). The number and its standard deviation of invaded cells when were cultured subconfluently $\left(45,000 \pm 7,000\right.$ cells $\left./ \mathrm{cm}^{2}\right)$ was $9,400 \pm 2,700$, and that when cultured confluently $\left(75,000 \pm 10,000\right.$ cells/ $\left.\mathrm{cm}^{2}\right)$ was $6,400 \pm 2,400$. Then, we chose the sparse cell density for the present in vitro invasion assay. First we examined the invasiveness, and the result showed that HSC-3 cells were most

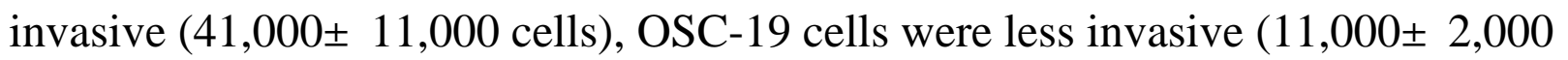

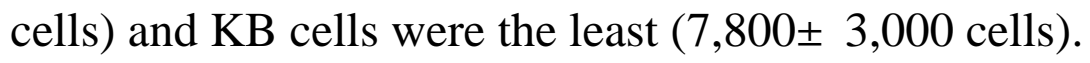




\section{Inhibition of invasion by synthetic peptides}

We examined the dose dependent inhibitory effect of peptides, using RGDS on OSC-19 cell invasion (Figure 1). Since $0.3 \mu \mathrm{mol} /$ chamber of RGDS inhibited the invasion, we used that amount for all peptides. Inhibitory effects of these peptides used were shown in Figure 2. The significant difference of those inhibition were determined by being compared with those of RGES peptide. RGDS showed a significant inhibition effect on OSC-19 cells. Laminin-derived YIGSR peptide significantly suppressed invasion of OSC-19 cells. Distinct laminin-derived IKVAV peptide significantly inhibited the invasion of HSC-3 cells, but not that of OSC-19 cells. Vitronectin-derived RGDV peptide showed significant inhibitory effects on all cell lines examined. RGDT sequence within collagen did not inhibit apparently invasion of all cell lines. RGD peptide, which does not function alone and is plausible to lack information determining receptor specificity (Yamada 1991), did not influence the invasion of OSC-19, HSC-3 and KB cells.

\section{Attachment to extracellular matrix proteins}

We examined the ability of cells to attach to purified intact proteins, fibronectin, laminin, vitronectin, collagen type IV which are involved in the invasion assay system (Figure 3). All cell lines were adhered promptly to fibronectin and collagen type IV within $1 \mathrm{hr}$. All cells showed time lag for adhesion to vitronectin, and OSC-19 cells and HSC-3 cells also showed delayed adhesion to laminin. KB cells were not adhered to laminin. This could be the reason why KB cells were not inhibited by laminin-derived peptides of IKVAV and YIGSR. To clarify the inhibitory effect of RGDV peptide on cell attachment, the other attachment inhibition assay has been done as follows; 
culture cells which were pretreated with RGDV or RGDS peptide were placed on vitronectin or fibronectin, followed by attachment assay for $2 \mathrm{hr}$. The result showed both peptides inhibited attachment of cells to vitronectin, and RGDV inhibited it more efficiently than RGDS. RGDV also inhibited the attachment to fibronectin, although it was less effective than the attachment to vitronectin (Fig. 4). This indicates that RGDV inhibits chiefly attachment of cells to vitronectin which has RGDV sequences. Thus, it is suspected that vitronectin receptors of $\alpha v$ integrins would be involved in the inhibitory effect of RGDV on the cellular attachment and invasion. Nextly, we performed the inhibition assay of the attachment using anti- $\alpha v$ integrins to clarify the implication of $\alpha v$ integrins in attachment of the cells to vitronectin. The result showed that anti- $\alpha \mathrm{v}$ antibodies inhibited the attachment of all cell lines to vitronectin, whereas anti- $\beta 1$ integrin antibodies did not (Fig. 5).

\section{Integrin expression}

125I-surface labeling and immunoprecipitation by polyclonal anti- $\alpha v \beta 3$ antibodies showed that two bands of Mr 160 and 95 kDa in HSC-3 cells indicating $\alpha \mathrm{v}$ and $\beta 3$, respectively, and a single band of $160 \mathrm{kDa}$ in OSC-19 cells indicating $\alpha \mathrm{v}$. We further investigated expression of integrins on vitronectin, fibronectin, laminin and collagen type IV, at $2 \mathrm{hr}$ after incubation when all cells are supposed to attach to ligands except for KB cells on laminin by immunofluorescent microscopy (Fig. 6). $\quad \beta 5$ and $\alpha \mathrm{v}$ were detected in all cell lines. $\quad \beta 3$ was detected only in HSC-3 cells. Their staining patterns were diffuse and there was no preferential localization on cell membranes. All cell lines were also positive for anti- $\alpha 2 \beta 1$ and $\alpha 3 \beta 1$ antibodies. $\quad \alpha 5 \beta 1$ integrin was not clearly shown in OSC-19, HSC-3 and KB cells. 


\section{DISCUSSION}

Integrins play a key role in cell-matrix interaction in physiological conditions, and it has been reported that with malignant transformation certain type of integrin were upregulated and involved in tumor progression and metastasis (Ruoslahti and Giancotti 1989; Albelda 1993; Evans 1992). In the present study, we examined the correlation between invasiveness and adhesiveness of three squamous carcinoma cell lines with a particular attention to the inhibitory effect of adhesion oligopeptides on the invasion model. First, we checked three different cell lines in terms of invasiveness using an in vitro invasion assay system which have become a useful tool for evaluating cancer invasion. In fact there were many reports that have substantiated positive correlation of the invasive properties with the ability of cells to invade matrigel (Kramer et al. 1986; Albini et al. 1984; Parish et al. 1992). In the present invasion study, HSC-3 cells and OSC-19 cells were invasive, and KB cells were less invasive. Previously, Kawahara et al. (1993) examined comparatively OSC-19 and KB cells, and showed that OSC-19 cells of infiltrating into the subcutaneous tissue of nude mice were able to invade into collagen gel, while $\mathrm{KB}$ cells growing expandingly in nude mice were not capable of infiltrating in the gel. Such a difference of invasiveness may correlate to some extent with cell-matrix interaction through cell adhesion molecules, because in the attachment assay KB cells were specifically not adhere to laminin and anti- $\alpha \mathrm{v}$ integrin antibody inhibited the attachment of cells to vitroenctin.

Secondly, we could demonstrated in the competitive inhibition assay using different synthetic peptides that three different cell lines were commonly suppressed the penetration through matrigel only by RGDV, vitronectin-derived 
tetrapeptide. Tetrapeptides we used, RGDV, RGDS and RGDT seem to inhibit binding to all RGD-dependent integrins non-specifically, as RGDS inhibits the attachment of the cells to RGD-containing matrix proteins, vitronectin, fibronectin and fibrinogen (Hirano et al. 1991). In general, RGD-containing oligopeptides, however, show distinct effect on perturbing cell-matrix interaction (Hirano et al. 1991; Kouns et al. 1992; Chen and Hawiger 1991) depending on X of RGDX (Hirano et al. 1991; Pierscbacher and Ruoslahti 1984). RGDS, RGDV, RGDF, RGDT, and RGDA are known to be active (Hirano et al. 1991). Scarborough et al. (1993) clarified that disintegrins containing RGDW sequences were specific for integrin $\alpha$ IIb $\beta 3$ and RGDNP-containing disintegrins were specific for integrin $\alpha v \beta 3$. The longer sequences of fibronectin containing a RGD sequence has the higher affinity to $\alpha 5 \beta 1$, although an RGD peptide has little activity (Pierscbacher and Ruoslahti 1984). These data indicate that certain amino acid sequences have strong affinity to the corresponding integrins. Actually, in our study RGDV was the most effective peptide that inhibits competitively cell invasion and attachment, suggesting that valine following aspartic acid would be crucial in the present cell-matrix attachment event of squamous carcinoma cells. The presence of RGDV might perturb $\alpha \mathrm{v}$ integrin expression; $\alpha v \beta 5$ in OSC-19 and KB cells, and $\alpha v \beta 5$ and $\alpha v \beta 3$ in HSC-19 cells. Our inhibition data of the attachment assay confirmed that RGDV rather than RGDS clearly reduced cell attachment to vitronectin. Furthermore, the attachment of these cell lines to vitronectin was inhibited by anti- $\alpha \mathrm{v}$ integrin antibodies. These phenomena remind us that cells adhere to vitronectin by using $\alpha \mathrm{v}$ - integrins, as is known well that receptors for vitronectin are exclusively $\alpha \mathrm{v}$ integrins of $\alpha v \beta 1$ (Zhang et al. 1993), $\alpha v \beta 3$, $\alpha v \beta 5$ (Smith et al. 1990) and $\alpha v \beta 8$ (Moyle et al. 1991) in a RGD-dependent manner besides $\alpha \operatorname{IIb} \beta 3$ of the platelet 
integrin (Kouns et al. 1992). RGDV peptide which is the selective sequence of vitronectin would result in having more avidity to $\alpha \mathrm{v}$-integrins than RGDS does. Thus, it is presumed that RGDV inhibits the invasive ability by interfering the attachment of $\alpha \mathrm{v}$-integrins to macromolecules, particularly vitronectin. The importance of $\alpha \mathrm{v}$ integrins would not be a universal phenomenon in malignant tumors, because a variety of malignant tumors show distinct integrin patterns reflecting the expansion of original cells (Korhonen et al. 1992; Miettinen et al. 1993). However, it is important to remind that $\alpha v \beta 5$ integrin was originally discovered from epithelial cell-derived carcinoma cells (Smith et al. 1990), and normal keratinocytes have $\alpha v \beta 5$ (Marchisio et al. 1991; Adams and Watt 1991).

There are many reports on the role of $\alpha \mathrm{v}$ integrin in melanoma cell invasiveness. For example, in melanoma cells a stable transfection of a cDNA encoding $\alpha \mathrm{v}$ integrin subunit resulted in a dramatic increased tumorigenicity (Felding-Habermann et al. 1992) and $\alpha v \beta 3$ integrin expression is linked to the tumor progression (Cheresh 1991; Nip et al. 1992) and melanoma cell migration (Leaversely et al. 1992). In carcinoma, renal cell carcinomas which express $\alpha v$ integrins have worse prognosis (Korhonen et al. 1992). These facts imply that the phenotype with this integrin may be responsible for a wide range of migratory and invasive event of cells. As shown in the present study, $\alpha v \beta 3$ and/or $\alpha v \beta 5$ particularly recognized in HSC-3 cells could contribute to the invasive property

Both HSC-3 and OSC-19 cells, whose invasion was inhibited by lamininderived peptides, IKVAV or YIGSR, adhered well to laminin. YIGSR has been reported to enhance metastasis (Graf et al. 1987; Iwamoto et al. 1987). IKVAV also has been said to have an important role in invasion (Tashiro et al. 1989). In the present assay, IKVAV for HSC-3 and YIGSR for OSC-19 were inhibitory peptides. KB cells which did not attach to laminin were not inhibited by 
IKVAV and YIGSR. Cell adhesion molecules to laminin are $\alpha 6 \beta 1, \alpha 6 \beta 4$, YIGSR receptor and IKVAV receptor. Thus, it is reasonable to think that invasiveness of squamous carcinoma cell lines is partly regulated by $\alpha v$-integrin expression and it may be possible to inhibit cell invasion by the competitive cell binding domain peptides. 


\section{REFERENCES}

Adams JC, Watt FM (1991) Expression of $\beta 1, \beta 3, \beta 4$ and $\beta 5$ integrins by human epidermal keratinocytes and non-diferentiating keratinocytes. J Cell Biol 115: 829-841

Albelda SM (1993) Biology of disease: Role of integrins and other cell adhesion molecules in tumor progression and metastasis. Lab Invest 68: 4-17

Albini A, Iwamoto Y, Kleinman HK, Martin GR, Anderson SA, Kozlowsky JM, McEwan RN (1987) A rapid in vitro assay for quantitating the invasive potential of tumor cells. Cancer Res 47: 3239-3245

Chen CS Hawiger J (1991) Reactivity of synthetic peptide analogs of adhesive proteins in regard to the interaction of human endothelial cells with extracellular matrix. Blood 77: 2200-2206

Cheresh DA (1991) Structure, function and biological properties of integrin $\alpha v \beta 3$ on human melanoma cells. Cancer Meta Rev 10: 3-10

Eagle H (1955) Propagation in a fluid medium of a human epidermoid carcinoma, strain KB. Proc Soc Exp Biol Med 89: 362-364

Evans CW (1992) Cell adhesion and metastasis. Cell Biol Int Rep 16: 1-10

Felding-Habermann B, Mueller BM, Romerdahl CA, Cheresh DA (1992) Involvement of integrin $\alpha \mathrm{v}$ gene expression in human melanoma tumorigenicity. J Clin Invest $\quad$ 89: 2018-2022

Gladson CL, Cheresh DA (1991) Glioblastoma expression of vitronectin and the $\alpha v \beta 3$ integrin. Adhesion mechanism for transformed glial cells. J Clin Invest 88: 1924-1932

Graf J, Iwamoto Y, Sasaki M, Martin GR, Kleinman HK, Robey FA, Yamada Y (1987) Identification of an amino acid sequence in laminin mediating cell attachment, chemotaxis, and receptor binding. Cell 48: 989-996 
Hirano Y, Kando Y, Hayashi T, Goto K, Nakajima A (1991) Synthesis and cell attachment activity of bioactive oligopeptides: RGD, RGDS, RGDV, and RGDT. J Biomed Mater Res 25: 1523-1534

Huschtscha LI, Lucibello FC, Bodmer WF (1989) A rapid micro method for counting cells "in situ" using a fluorogenic alkaline phosphatase enzyme assay. In Vitro Cell Dev Biol 25: 105-107

Iwamoto Y, Robey FA, Graf J, Sasaki M, Kleinman HK, Yamada Y, Martin GR (1987) YIGSR, a synthetic laminin pentapeptide, inhibits experimental metastasis formation. Science 238: 1132-1134

Kawahara E, Schiroo M, Nakanishi I, Migita S (1989) The role of fibronectin in the development of experimental amyloidosis. Am J Pathol 134: 1305-1314 Kawahara E, Okada Y, Nakanishi I, Iwata K, Kojima S, Kumagai S, Yamamoto E (1993) The expression of invasive behavior of differentiated squamous carcinoma cell line evaluated by an in vitro invasion model. Jpn J Cancer Res 84: $409-418$

Kleinman HK, McGarvey ML, Liotta LA, Robey PG, Tryggvason K, Martin GR (1982) Isolation and characterization of type IV procollagen, laminin, and heparan sulfate proteoglycan from the EHS sarcoma. Biochemistry 21: 6188-6193

Korhonen M, Laitinen L, Ylänne L, Koukoulis GK, Quaranta V, Juusela H, Gould VE, Virtanen I (1992) Integrin distributions in renal cell carcinomas of various grades of malignancy. Am J Pathol 141: 1161-1171

Kouns WC, Kirchhofer D, Hadváry P, Edenhofer A, Weller T, Pfenninger G, Baumgartner HR, Jennings LK, Steiner B (1992) Reversible conformational changes induced in glycoprotein IIb-IIIa by a potent and selective peptidomimetic inhibitor. Blood 80: 2539-2547 
Kramer RH, Bensch KG, Wong J (1986) Invasion of reconstituted basement membrane matrix by metastatic human tumor cells. Cancer Res 46: 19801989 
Larjava H, Pletonen J, Akiyama SK, Yamada SS, Gralnick HR, Uitto J, Yamada KM (1990) Novel function for $\beta 1$ integrins in keratinocyte cell-cell interactions. J Cell Biol 110: 803-815

Leavesley DI, Ferguson GD, Wayner EA, Cheresh DA (1992) Requirement of the integrin $\beta 3$ subunit for carcinoma cell spreading or migration on vitronectin and fibrinogen. J Cell Biol 117: 1101-1107

Marchisio PC, Bondanza S, Cremona O, Cancedda R, De Luca M (1991) Polarized expression of integrin receptors ( $\alpha 6 \beta 4, \alpha 2 \beta 1, \alpha 3 \beta 1$, and $\alpha v \beta 5)$ and their relationship with the cytoskeleton and basement membrane matrix in cultured human keratrinocytes. J Cell Biol 112: 761-773

Miettinen M, Castello R, Wayner E, Schwarting R (1993) Distribution of VLA integrins in solid tumors. Emergence of tumor-type related expression patterns in carcinomas and sarcomas. Am J Pathol 142: 1009-1018

Minamoto T, Ooi A, Okada Y, Mai M, Nagai Y, Nakanishi I (1988) Desmoplastic reaction of gastric carcinoma: a light- and electron-microscopic immunohistochemical analysis using collagen type-specific antibodies. Hum Pathol 19: $815-821$

Momose F, Araida T, Negishi A, Ichijo H, Shioda S, Sasaki S (1989) Variant sublines with different metastatic potentials selected in nude mice from human oral squamous cell carcinomas. J Oral Pathol Med 18: 391-395

Mosmann T (1983) Rapid colorimetric assay for cellular growth and survival. Application to proliferation and cytotoxicity assays. J Immunol Methods 65: 55-63

Moyle M, Napier MA, McLean W (1991) Cloning and expression of a divergent integrin subunit $\beta 8$. J Biol Chem 266: 19650-19658 
Nelson-Rees WA, Flandermeyer RR, Hawthorne PK (1974) Banded marker chromosomes as indicators of intraspecies cellular contamination. Science 184: 1093-1096

Nip J, Shibata H, Loskutoff DJ, Cheresh DA, Brodt P (1992) Human melanoma cells derived from lymphatic metastases use integrin $\alpha v \beta 3$ to adhere to lymph node vitronectin. J Clin Invest 90: 1406-1413

Parish CR, Jakobsen KB, Coombe DR (1992) A basement membrane permeability assay which correlates with the metastatic potential of tumor cells. Int J Cancer 52: 378-383

Pasqualini R, Bodorova J, Ye S, Hemler ME (1993) A study of the structure, function and distribution of $\beta 5$ integrins using novel anti- $\beta 5$ monoclonal antibodies. J Cell Sci 105: 101-111

Pierschbacher MD, Ruoslahti E (1984) Variants of the cell recognition site of fibronectin that retain attachment promoting activity. Proc Natl Acad Sci USA 81: 5985-5988

Ruoslahti E, Giancotti EG (1989) Integrins and tumor cell dissemination. Cancer Cells 1: 119-126

Scarborough RM, Rose JW, Naughton MA, Philipps DR, Nannizzi L, Arfsten A, Campbell AM, Charo IF (1993) Characterization of the integrin specificities of disintegrins isolated from American pit viper venoms. J Biol Chem 268: 1058-1065

Seftor REB, Seftor EA, Gehlsen KR, Stetler-Stevenson WG, Brown PD, Ruoslahti E, Hendrix MJC (1992) Role of the $\alpha v \beta 3$ integrin in human melanoma cell invasion. Proc Natl Acad Sci USA 89: 1557-1561

Smith JW, Vestal DJ, Irwin SV, Burke TA, Cheresh DA (1990) Purification and functional characterization of integrin $\alpha v \beta 5$. J Biol Chem 265: 11008- 
Sonnenberg A, Janssen H, Hogervorst F, Calafat J, Hilgers J (1987) A complex of platelet glycoproteins Ic and IIa identified by a rat monoclonal antibody. J Biol Chem 262: 10376-10383

Steiner B, Cousot D, Trzeciak A, Gillessen D, Hadváry P (1989) Ca ${ }^{2+}$ dependent binding of a synthetic Arg-Gly-Asp (RGD) peptide to a single site on the purified platelet glycoprotein IIb-IIIa complex. J Biol Chem 264: 1310213108

Suzuki S, Oldenberg Å, Hayman EG, Pierschbacher MD, Ruoslahti E (1985) Complete amino acid sequence of human vitronectin deduced from cDNA. Similarity of cell attachment sites in vitronectin and fibronectin. The EMBO Journal 4: 2519-2524

Tashiro K, Sephel GC, Weeks B, Sasaki M, Martin GR, Kleinman HK, Yamada Y (1989) A synthetic peptide containing the IKVAV sequence from the A chain of laminin mediated cell attachment, migration, and neurite outgrowth. J Biol Chem 264: 16174-16182

Ueda Y, Nakanishi I (1989) Immunohistochemical and biochemical studies on the collagenous proteins of human osteosarcomas. Virchow Arch [B] Cell Pathol 58: 79-88

Vogel BE, Tarone G, Giancotti FG, Gailit J, Ruoslahti E (1990) A novel fibronectin receptor with an unexpected subunit composition ( $\alpha \mathrm{v} \beta 1)$. J Biol Chem 265: 5934-5937

Yamada KM (1991) Adhesive recognition sequences. J Biol Chem 266: 12809-12812

Yatohgo T, Izumi M, Kashiwagi H, Hayashi M (1988) Novel purification of vitronectin from human plasma by heparin affinity chromatography. Cell 
Struct Funct 13: 281-292

Yokoi T, Homma H, Odajima T (1988) Establishment and characterization of OSC-19 cell line in serum- and protein-free culture. Tumor Res 24: 1-17

Zhang Z, Morla AO, Vuori K, Bauer JS, Juliano RL, Ruoslahti E (1993) The $\alpha v \beta 1$ integrin functions as a fibronectin receptor but does not support fibronectin matrix assembly and cell migration on fibronectin. J Cell Biol 122: $235-242$ 


\section{FIGURE LEGEND}

Fig. 1. Dose dependent inhibitory effect of RGDS oligopeptides on OSC-19 cell invasion.

Fig. 2. Inhibitory effects of oligopeptides on carcinoma cell invasion through matrigel. Cells were treated with $0.3 \mu \mathrm{mol} / \mathrm{chamber}$ of peptides. Invasion of three cell lines is commonly inhibited by RGDV. Asterisk stands for significant inhibition in comparison with RGES $(\mathrm{P}<0.05)$. Each bar represents the mean \pm the standard error of triplicates.

Fig. 3. Time course of attachment assay. OSC-19 cells (A), HSC-3 cells (B) and KB cells (C) adhere to collagen type IV ( $\mathbf{O}$ ) and fibronectin $(\bigcirc)$ rapidly. All cells adhere well to vitronectin ( $\boldsymbol{\square}$ ) but there is time lag in comparison with adhesion to collagen and fibronectin (A, B, C). OSC-19 cells and HSC-3 cells adhere to laminin $(\square)$ in a similar fashion to vitronectin (A, B). KB cells do not adhere to laminin (C). Each point represents the mean \pm the standard error of tiplicates.

Fig. 4. Inhibitory effects of RGDS and RGDV peptides on cell attachment assay to fibronectin and vitronectin. Cells $\left(1 \times 10^{5}\right.$ cells/ well) were pretreated with synthetic peptides ( $0.3 \mu \mathrm{mol} /$ well) for $60 \mathrm{~min}$, incubated on each substrate for $2 \mathrm{hr}$. RGDV inhibits more efficiently than RGDS in the attachment of cells to vitronectin and fibronectin. The data shown in this figure are the mean values ( \pm the standard deviation) of triplicate determinations.

Fig. 5. Inhibitory effects of antibodies on attachment of carcinoma cells to vitronectin. Three cell lines are all inhibited by polyclonal anti- $\alpha$ v integrin antibodies, and not inhibited by polyclonal anti- $\beta 1$ antibodies. Each bar represents the mean \pm the standard error of triplicates. 
Fig. 6. Immunoprecipitation of integrins subunits expressed on carcinoma cell lines. Lysates of 125I-surface labeled OSC-19 (lane 1) and HSC-3 cells (lane 2) were immunoprecipitated with polyclonal anti- $\alpha \mathrm{v} \beta 3$ antibodies. Immunoprecipitated samples were separated SDS-PAGE (7.5\% acrylamide) in non-reducing condition, and the bands were visualized by autoradiography. Molecular markers are indicated on the left.

Fig. 7. Immunofluorescent microscopic demonstration of integrin $\beta 5$ (A, E), $\beta 3$ (B, F), $\alpha 3 \beta 1$ (C, G) and $\alpha 5$ (D, H) in HSC-3 cells (A-D) and OSC-19 cells (E-H). Cells were cultured for $2 \mathrm{hr}$ in serum-free medium on vitronectin (A, B, E, F), fibronectin $(C, G)$ and type IV collagen $(D, H) . \quad \beta 5$ is positive in HSC-cells in a dot-like or fibrillar pattern, and OSC-19 cells in a diffuse or fibrillar pattern. $\quad \beta 3$ was positive in HSC-3 cells, but not in OSC-19 cells. $\quad \alpha 3 \beta 1$ is positive in HSC-3 and OSC-19 cells. Clear positivity for $\alpha 5 \beta 1$ is not shown in HSC-3 and OSC-19 cells. 